\title{
Changing perspectives in Legal Education: competence-based learning and the possibilities to improve access to justice via mediation skills
}

\author{
Loussia P. Musse Felix and André Gomma de Azevedo*
}

First publication online: 30 June 2015

\begin{abstract}
As one of the major Brazilian Law Schools, the University of Brasilia School of Law is at the forefront of a competence-based dispute resolution programme to be used in legal education and within the Brazilian Court system. Changes in Legal Education around the world obviate the need to integrate theoretical and practical perspectives at all levels in the formal training of new professionals in the field of Law. The University of Brasilia School of Law has participated in Tuning Latin America since 2006 and has recently adopted a Curriculum that embraces competence-based learning as part of a major change geared to bringing social, cultural and political effectiveness into the teaching of Law. This paper outlines the challenges facing the adoption of collaborative approaches to dispute resolution in the legal arena and the meta-competences and competences it entails.
\end{abstract}

Keywords: Competence based learning; legal education; mediation skills; negotiation practices; Tuning Latin America; collaborative approaches; dispute resolution.

\section{Introduction}

This article offers an analysis of the possibilities and the forms in which competences may be adopted in the legal arena as pertains to the future training of professionals. Law has been a topic in the ALFA Tuning Project since 2006 when specific competences were established and, later, pursuant the methodology adopted, were validated by a large multinational group of scholars, professionals, students, and recent graduates. The subsequent refinement of these competencies five years later brought, among other results, ${ }^{1}$ a more qualitative approach that fosters a culture of

* Dr. Loussia Penha Musse Felix (loussia.felix@gmail.com) is Professor of Law at the University of Brasília (Brazil). André Gomma de Azevedo (andregommadeazevedo@gmail. com), LL .M, is an LL.D. candidate at the University of Brasilia Law School (Brazil).

1 The experience of Law at the Tuning Project is offered in the final publication produced as part of Tuning Latin America. In Higher Education in Latin America: reflections and 
seeking collaborative solutions by the newly minted professionals of the field of Law.

Competences related to collaborative techniques for the resolution of conflicts might become one of the theoretical-methodological pillars of the B.A. degree in Law in societies that find themselves undergoing a shift in their social structures, including the modes to access the judicial system.

Latin America and Brazil both have a history of political domination, blatant disregard to the rule of law, and inefficiency of the judicial system that have a direct impact on legal education. The contemporary scenario, with social demands for justice and the effective protection of human rights, contrasts with the legacy of clear violations which occurred when military dictatorships swept the continent ${ }^{2}$ and issues a clear call for models of legal education supporting less authoritative societies (at least at the constitutional level). There is a need to consolidate experiences that harmonize the social demands, pedagogical innovations, and progress made in the process of bringing stability to the democratic state. This is an urgent task for those active in the various fronts of legal education today. These experiences offer an alternative to the labyrinth decried by García Villegas in his apt description of every country of the continent:

There is a substantial gap in Latin America between, on the one hand, written norms, which professors teach in Law schools, legislators enact and judges enforce, and, on the other, people's behavior, including that of those professors and legislators. Latin Americans live in a kind of schizophrenic society, in which there is much talk of what should be and much is enacted about duties, but little of what is enacted is actually practiced.

Embracing the idea that a purely formalistic legal approach is no longer, if it ever was, of any use in the extremely lengthy process of educating legal

perspectives on Law describes the trajectory, objectives and methodology that paved the way for the collective results of the project but also valuable material on the competences, meta profile, competence based learning, along with information on the origins of the field of knowledge on the continent. See: Loussia P. Musse Felix et al., Higher Education in Latin America: reflections and perspectives on Law (Bilbao: Deusto Univerty Press, 2014).

${ }^{2}$ From the mid-1980s on, various countries of Latin America (among them Brazil) embarked on democratic transitions. One of the more complex aspects of this phenomenon were the forms established by the new judicial systems to confront the grave violations of human rights perpetrated by authoritarian regimes. Various conceptions of transitional justice arising from the Nuremberg Tribunal acquired new and distinct forms within the different Latin American judicial systems (José Maria Gómez, "Justiça transicional, humanitarismo compassivo e ordem global liberal pós-guerra fria," in Direitos Huanos: Justiça, Verdade e Memória, ed. Bethania Assy, Carolina Campos Melo, João Ricardo Dornelles and José María Gómez (Rio de Janeiro: Lumen Juris, 2012), 262-263. 
professionals in Latin American law schools, the issue is reframed as to how to best identify pedagogical scenarios and methodologies that are truly effective. The reference to the Meta-Profile in Law is a good example of how a common language can be established among the myriad forms that professional activities related to a Law Degree are able to provide. ${ }^{3}$

The complex task of defining a common goal for the process and the aims of legal education in a regional perspective can be condensed in the Meta-Profile established after a fascinating and arduous round of team work conducted by the Law Group of Tuning Latin America: ${ }^{4}$ As a major metacompetence in the profile is able to ethically and effectively commit to persons and institutions by finding and implementing solutions to real problems in line with the protections granted by human rights. ${ }^{5}$

Presenting a clear opportunity for the subject of Law to promote competencies in legal education in Latin America that encourage a culture of collaborative solution to controversies, it also breaks with the sharper secular practices of contentious or litigious systems of justice which pit actors with opposing interests in a legal conflict.

This meta-competency has an affinity with the capacity to effectively utilize collaborative methods of conflict resolution, since a system becoming more gradually effective in the protection of human rights presupposes confidence in the solutions adopted by the legitimate participants in judicial and extra-judicial proceedings.

However, for the purposes of this article, we explore the competency adopted by the group of promotion of the culture of dialogue and the use of alternative means for the creative resolution of conflicts. We use as our

${ }^{3}$ Meta-profiles explain the relationship between generic and specific competencies within a subject area. They constitute a more specific statement of agreements and limits in terms of the convergence that has been reached in order to recognise a certain qualification. They imply a reference for the subject area with regard to what is central, common, and necessary, in order to be able to recognise a given qualification (Felix, Higher Education in Latin America, 33).

${ }^{4}$ The area of Law participated in the ALFA Tuning Project since the general meeting in Costa Rica in February 2006 that established specific competencies for each field of knowledge.

5 The competence to find solutions in the human rights protection hallmark should be acquired not only by theoretical development of major abstract and principiological narratives. In Latin America these abstract discussions were greatly influenced by the neoconstitutional school of thought, which comprises fundamental rights, constitutional jurisdiction and constitutionalism. Under this perspective, which we associate with Rodrigo Kaufmann, "human rights are not linked to the conceptualization process but to the field of action; not linked to the field of reason but to the field of tolerance and sensibility that may only be obtained by the experience of life" (page 121) 
example the Brazilian experience in the creation of the Permanent Center for Mediation and Conciliation (NUPEMEC) in several jurisdictions.

In 1999 a research group on Arbitration, Mediation and Negotiation was formed with the purpose of creating competence-based teaching material on Amicable Dispute Resolution. Since then, this group, which is currently called Research Group on Appropriate Dispute Resolution, has produced a handbook on court mediation, ${ }^{6} 6$ videos, ${ }^{7}$ over 30 role plays to be used in competence based trainings, supervision forms, among other teaching material printed by the National Council of Justice, by several State Courts and by the Ministry of Justice.

\section{Introduction to Negotiation and Mediation Practices}

Collaborative practices in Brazil have dated to statutory law enacted before the $17^{\text {th }}$ century during the period of Portuguese Colonization. These approaches such as conciliation (in Portuguese, referred to as conciliação) and settlement conferences (also called conciliação) were conducted intuitively, i.e. without any theoretical bases for peacemaking approaches. During this period, conciliators were often told to do whatever they deemed appropriate to dissuade parties from litigation and stimulate them to reach an agreement. Brazilian practice resembled to great extent the Italian approach which was often criticized for "excessive and inopportune persistence activities by judges significantly more concerned in clearing their dockets than in reaching peace among contenders."

Until late $19^{\text {th }}$ century, there were no training programs or handbooks on how to negotiate, how to conduct conciliations or any other collaborative practices in Brazil. Basically, the intuitive practice of conciliatory processes were derived from what was considered at the time to be innate skills. Knowing how to speak mildly and by these communicative abilities be able to reduce the tension among the parties was perceived as being a set of skills existing in one from birth or taught in a core set of family values in the home environment.

In mid 1990s, the Brazilian courts started inviting law students to volunteer as conciliators. Slowly the intuitive practice of conciliation

${ }^{6}$ André Gomma Azevedo, Manual de Mediação Judicial (Brasilia: Ministry of Justice and United Nations Development Program (PNUD)), 2013.

${ }^{7}$ See https://www.youtube.com/watch?v=NJ7nCCJp9SM, visited on March 1 ${ }^{\text {st }}, 2015$.

${ }^{8}$ Carnelutti Francesco, Instituições do Processo Civil, vol. 2 (São Paulo: Classic Book, 2000), 70. 
evolved into a set of approaches derived from the North American experience in mediation. In a recent publication of the National Council of Justice (NCJ), it was stated that conciliation may be presently defined as an expeditious process in which parties are assisted by third parties neutral to the conflict who will, by the use of proper techniques, assist in the resolution of a conflict. Still according to this publication, several distinctive points were originally established to distinguish mediation and conciliation. Among other distinctions, it was suggested that: i) mediation pursued the resolution of a conflict while conciliation only directed itself towards a settlement; ii) mediation pursued the restoration of the social relationship between disputing parties while conciliation was directed towards the end of litigation, and iii) mediation would last longer and involve a more technical approach than conciliation.

After a substantial change in the structure of conciliation training, Brazilian courts started considering that a modern judiciary may not allow conciliators to act without a minimum theoretical and technical basis. Based on this understanding, the distinctions between conciliation and mediation started to progressively decrease. Currently, the public policy set forth by the NCJ requires mediators and conciliators, including those who are still attending law school, to develop competences by means of negotiation workshops and conciliator / mediator qualification programs.

Thus, early conciliation training was conducted on a fixed duration basis and without clearly defined programs. In the last twenty years, the original lectures on conciliation became substantially similar to the mediation qualification programs described in the next section. Although this program was designed for court mediation, the same program is being recommended by NCJ to law schools with clinical programs in mediation. Moreover, the significant change from training programs based on time to programs based on competences, is being implicitly endorsed by the Judiciary as a means of obtaining a better fit between law school curricula and the work environment.

\section{Dimensions of a Mediator Qualification Program}

The issue as to how to qualify an individual as a mediator has already been broadly approached by the specialized texts. ${ }^{9}$ As one devises and

9 The so-called transformative, reflective, and dialogical mediation approaches are anchored in empirical praxis and are not described in doctrinal works, which specifically define them. 
conceives any enabling program, the very first step involves identifying the specific training needs and goals. Thus, it is fundamental to have a grasp of the desirable theoretical components, skills, attitudes and organizational outcomes when specifying the desired outcomes for the mediators's qualification program. ${ }^{10}$ The mediation skills development process, according to the predominant guidelines ${ }^{11}$ consist of five interrelated parts, namely: a) Selection; b) Theoretical instruction; c) Practical observation of mediation; d) supervised internship; and e) Users's satisfaction assessment at the end of the supervised internship.

\section{Selection}

A significant portion of the legal mediators's qualification process involves the selection of participants in the mediator qualification program. It is currently ${ }^{12}$ suggested that a number of interviews with interested parties be conducted in order to verify the level of knowledge on mediation and potential adherence to the program. It is not uncommon to have interested parties, be they civil servants of the legal branch or external volunteers such as law students, participate in programs without understanding what is expected from mediators. Many times, individuals enroll in such programs

${ }^{10}$ See Stephanie A Henning, "A Framework for Developing Mediator Certification Programs," Harvard Negotiation Law Review 4 (1999): 189; Robert A Baruch Bush,. "One Size Does Not Fit All: A Pluralistic Approach to Mediator Performance Testing and Quality Assurance, Ohio State Journal on Dispute Resolution 19; Joseph B. Stulberg and Lela P Love, Conducting the Mediator Skill-Building Training Program (Lansing: State Court Administrative Office, 1997); Gregg B Walker, "Training Mediators: Teaching About Ethical Concerns and Obligations," Mediation Quarterly 33, vol. 9 (1988); Linda Fisher, "Managing Programmes, Quality Control and Training," in Alternative Dispute Resolution, ed. Jane Mugford (Canberra: Australian Institute of Criminology, 285); Christopher W. Moore, "Training Mediators For Family Dispute Resolution," Mediation Quarterly 79 (1983): 2; Sarah C.; Grebe, "Family Mediation Training Programs: Establishing Standards," Mediation Quarterly 13, (1988): 19; Suzanne J. Schmitz, "What Should we Teach in ADR Courses - Concepts and Skills for Lawyers Representing Clients in Mediation," Harvard Negotiation Law Review 6 (2001): 189; Joseph B. Stulberg and B. Ruth Montgomery,"Requisitos de Planejamento para Programas de Formação de Mediadores," in Estudos em Arbitragem, Mediação e Negociação Vol. 2, ed. André Gomma de Azevedo (Brasilia: Grupos de Pesquisa, 2002), 109-140.

${ }^{11}$ Such difficulties and unfolding solutions have also been identified in other nations. On the theme, see Joseph B. Stulberg and B. Ruth Montgomery, "Requisitos de Planejamento para Programas de Formação de Mediadores," in Estudos em Arbitragem, Mediação e Negociação (vol. 2), ed. André Gomma de Azevedo (Brasilia: Grupos de Pesquisa, 2002), 109-140.

${ }^{12}$ See 2 above. 
just for the sake of being better informed about this métier. In such latter cases, professionals have identified significantly negative results throughout the more advanced stages of the mediation qualification program, both in Brazil and abroad. For that reason, such interviews serve to identify the candidate's predisposition towards mid- to long-term engagement in the program. The interviews will also be helpful in selecting those individuals who are more prone to committing to the program, to continuous education and to supplementary reading.

Another proven praxis in presenting positive results throughout the programs involving law students and other external volunteers is to select participants who are well established professionals or among the highest percentile of their classes and have them engage as volunteers a few hours a week or a month. This also served to validate the (overqualified) volunteering activity in the legal mediation program. For instance, the Bahia and Rio de Janeiro Courts of Justice offer $\mathrm{PhD}$ professors who undertook these training sessions and often mediate for only four hours a week or even less. The relevance of such volunteering activity involving very highly qualified personnel acts as a driver in leveraging the participation of other highly qualified volunteers.

\section{Theoretical Instruction in Mediation}

The theoretical training portion of mediation is usually rather pragmatic and has proven to be a fulcrum in legal mediation qualification programs in Brazil. It is rather common in training sessions to overemphasize the theoretical portion to a point of allotting 100, 160 or even 360 hours of theoretical teaching in mediation programs. ${ }^{13}$

Unfortunately, many instructors in Brazil take too long to realize that, "there is nothing more practical than a good theory". ${ }^{14}$ The true importance of the theoretical training which allows the participant a prompt assessment of its practical usage in mediation has been overlooked by many. This occurs because training sessions presenting exceedingly theoretical abstraction generally do not effectively qualify aspiring mediators. For instance, a

${ }^{13}$ This also took place in other nations to a smaller degree. On the theme, see John M $v$. Haynes., Gretchen L. Haynes, and Larry Sun Fong, Mediation: Positive Conflict Management (Nova York: SUNY Press, 2004), xi, where it is suggested that "theory in excess without the ballast of practical experiences might be limiting and might unnecessarily coerce a mediator into a situation without pondering other possibilities in mediation".

${ }^{14}$ Haynes et al., Mediation: Positive Conflict Management, xv. 
training session that thoroughly offers a background of the circular-narrative model, or of the transformative model or the dialogical model will hardly be able to allow for a better practical toolset for the participant to thoroughly comment on historical components or on disparate components among various mediation models.

One of the seminal components of mediator qualification programs geared towards the analyses of competences involves transmitting theoretical knowledge to be used in the development of the participants skillset, which, along with a proper willingness to excel as a mediator, can lead to an effective mediation competency or to competency in mediation.

The training model based on competences and its comparison with the training models based on time will be discussed below. Currently a major portion of mediation trainings ${ }^{15}$ have started approaching competences. Among the main topics addressed during these skills training programs are theory of conflict, negotiation techniques, mediation techniques and mediation procedures.

\section{Observation of real cases}

A significant portion of training a new mediator involves observing more experienced mediators, preferably those who are technically deft. This serves the purpose of stimulating a new mediator to seek theoretical components and discover how the theory is applied in practice. ${ }^{16}$ The observation of a more experienced mediator in action should impress on the aspiring mediators that the whole process should take a number of years in order to reach a higher level of development of their mediation techniques. Unfortunately, in some Brazilian courts we notice that a number of conciliations and mediations are lead by under qualified facilitators and the exact opposite takes place. At the end of a theoretical portion of training, the new mediator should observe the more experienced professional who lacks finely tuned techniques. This leads the aspiring conciliator or mediator to believe him/herself to be perfectly skilled and already equipped to take on the role of a mediator. This is why self-supervising groups have been recommended in programs lacking more experienced mediators.

15 Stulberg, "Requisitos de Planejamento," 512.

${ }^{16}$ Lensky et al., "After how much training can you call yourself a mediator," (podcast recorded on February $\left.25^{\text {th }}, 2010\right)$, http://itunes.apple.com/podcast/cafe-mediate/id346857436. 
The self-supervising groups model consist of teams with six to eight participants each who necessarily attend the mediation sessions of each participant and discuss the techniques applied by co-mediators. This is a comediating activity due to the fact that new mediators must follow such a format: two facilitators acting concurrently as a means of sharing the learning experiences as to how the technique is to be applied in specific real cases. ${ }^{17}$ Such a guideline has been set as a federal public policy in compliance with the Handbook of Court Mediation ${ }^{18}$ that the NCJ, with the support of the Secretariat of Judiciary Reform at the Ministry of Justice, has published. The self-supervising group is able to follow up on their own supervisions and collate with the recommendations stated in the Handbook of Court Mediation. The Brazilian experience has shown that self-supervision in courts has proven to be more effective than supervision conducted by civil servants or mediators who are still to develop their mediation techniques.

In order to facilitate the transposition of theory into practice, the Handbook of Court Mediation recommends the adoption of a model in which the observer of such mediation sessions follows up on the observations with the use of a mediator observation form. Such form defines actions, procedures, practices and skills the observer must identify in the more experienced mediator being observed. We recommend a meeting between both aspiring and experienced mediators at the end of the observation session in order to elucidate any questions or applicational specifics on the techniques. A good practice is to have the supervisor and aspiring mediator discuss the observed techniques and clarify any pending doubts.

One practice which is gradually being phased out in Brazil involves requesting the aspiring mediator to observe a maximum number possible of mediating sessions and have him decide when he deems to be apt to act as a co-mediator. Such an approach does not require the aspiring mediator to discuss the transposition of the a portion of theory into the perceived praxis of the experienced mediator. This also allows for a rather dangerous conclusion that mediation might be developed via intuitive and impromptu means, i.e. without having theory incorporated into the apprentice's praxis.

17 Stulberg, "Requisitos de Planejamento," 518. On the theme, see Lela P Love, et al., "Practice Guidelines for Co-Mediation: Making Certain that Two Heads Are Better Than One," Mediation Quarterly 3, vol. 13 (1996); Martin A. Kranitz, Co-Mediation: Pros and Cons, in Divorce and Family Mediation: The Family Therapy Collections (James C. Hansen \& Sarah Child Grebe, Ed. Aspen, 1985) 71, 78.

18 The Handbook of Court Mediation is an orienting tool for such public policies involving technical qualification in mediation. The Handbook can be accessed via internet on the Brazilian Ministry of Justice and National Council of Justice websites. 


\section{Co-Mediation and Supervised Internship}

In most mediator training programs around the world ${ }^{19}$ one realizes that, by the end of the case observation, the aspiring mediators start co-mediating simpler cases with more experienced practitioners. In such cases, praxis recommends the supervisor to assess if the aspiring mediator has reasonably perceived and absorbed mediator traits and if she has conducted the process in such a way that allowed for co-mediator behavior in the presence of a more experienced practitioner. In such situation the apprentice is herself/ himself responsible for conducting the mediation. The supervisor or mentor intervenes only for constructive advancement. According to modern approaches, ${ }^{20}$ this is a safety system in the apprentice's learning process which leads the aspiring mediator remaining comfortable with the mediating dynamics and with managing the stakeholders's interactions. Common responses such as anxiety and diffidence usually subside as the apprentice co-mediates the first sessions with a supervisor.

Not surprisingly, many programs in Brazil cannot afford experienced supervisors and this is why co-mediating sessions are lead by two mediators or co-mediators with the same beginners' technical level who will need to assist one another throughout the development of their competences. In such model, both co-mediators are observed in their own self-supervising groups by four other apprentices with whom they review their mediating using two different forms. One uses the observer form and the other with practitioners using the supervisor form. By the end of the mediating session, the selfsupervising group will reconvene and discuss the cases. All questions will be recorded and forwarded to the instructor or supervisor at a coming meeting. The NCJ offers instructors's training courses where they recommend the instructors to meet via videoconference once a month with this selfsupervising group in order to clarify any questions regarding mediation techniques in practice.

Another recommended technique during the supervised traineeship stage involves having the supervisor observe the new mediator. In such a procedure, the apprentice co-mediates at the end of a certain number of cases with another mediator on a same par. At the same time, the supervisor observes the mediator in training who very probably will present proper behavior due to the experience accrued throughout the supervised traineeship period. The

19 See footnote 2 .

${ }^{20}$ Stulberg, "Requisitos de Planejamento," 519. 
supervisor is now only responsible for concluding his role in supervising as he monitors the apprentice's dealings of a new case, from beginning to end.

\section{e) User Satisfaction Assessment}

The last component of the qualification of a mediator involves the client satisfaction assessment. In this stage, the mediator to be certified is assessed by a user according to his expected competence as a new mediator. As a new quality management program is adopted, the mediators and their teams are able to understand better their standards and the users' satisfaction rates. It is also advisable to question subjects and have the supervisor undertake a user satisfaction survey to assess services using a mediator observation form. Since 2009, the NCJ has encouraged ${ }^{21}$ the Brazilian Courts of Law to evaluate conciliators and mediators according to the Likert scale using 5 options (Very Good, Good, Barely Acceptable, Poor, Very Poor) on the following criteria: i) Time elapsed throughout the conciliation; ii) Impartiality in conciliating; iii) Conciliator's courteous stance, attention and politeness; iv) Adequate treatment for the legal branch; and v) Assessment of the end result.

The five qualifying components mentioned above were conceived for use in training sessions and to develop competences; they were not devised to be used in programs exclusively based on duration. As the reader will realize further on, the programs based on competences refer to the expectations of the tasks the mediator will undertake, and are not merely abstract theoretical considerations. Such a shift in perspective changes the essence of the programs and also the outcomes of such learning experiences.

\section{Training Programs Based on Time and Programs Based on Competences}

The training model based on time (duration) has been used in various areas of knowledge with a pedagogical proposal based on the presentation of a number of theoretical models to participants (apprentices). A number of exams are also used to assess the acquisition of concepts and principles. ${ }^{22}$ The outcomes are all frequently compared with one with another in order to

${ }^{21}$ Movement for Conciliation Managing Committee, "Quality in Conciliation: Guidelines to Conciliators," accessed on December 20, 2011. http://www.cnj.jus.br/images/programas/ movimento-pela-conciliacao/qualidade-em-conciliacao-orientacaes-a-conciliadores.zip.

${ }^{22}$ Managing Committee of the Conciliation Movement, "Quality in Conciliation," (Powerpoint presentation held on November 6, 2009), http://www.cnj.jus.br/images/programas/ 
better gauge the command of the proposed technical model. In future training regarding knowledge of the standards positively valued in such model, it suffices to assess the adequateness of an applicant on a given public servants entrance examination.

However, approaches based on time have yielded unsatisfactory results for the qualification of mediators in recent years. They have also been deemed as inefficient when the goal is to qualify individuals and have them develop specific skills and tasks. For instance, the accreditation of aeronautical pilots takes place not only with theoretical knowledge, but with the development of practical competences in piloting aircrafts that, of course, do demand theoretical knowledge, but also require significant implementation of such knowledge throughout daily activities. It is clear that a mere participation in an aeronautical qualification program does not suffice; likewise a mediator requires specific theoretical knowledge and applying such specific theoretical knowledge in real cases. Thus, the mediator qualification pedagogical system based on time is not appropriate.

According to the Tuning Project, Competences are a combination of knowledge, understanding, skills and abilities. ${ }^{23}$ In other words, competences are set of skills, knowledge and attitudes that when orchestrated and strategically used allows for the attainment of success in all that is expected throughout the developments of the process ${ }^{24}$. Moreover, there is a consensus that competency in mediation involves the conjugation of mediation technical knowledge, (the skill, the know-how) and the attitude (the volition of acting). This is why mediator qualification programs in which there is exaggerated debate on mediation models (e.g., circular-narrative, dialogical, transformative, etc), or where there is too much time invested in creating distinction between conciliation and mediation, or programs which prefer longer hours than are truly necessary to convey the theoretical set of knowledge (to be exercised throughout the supervised traineeship period) end up proving to be inefficient.

Training based on competences, as opposed to those based on time, takes into consideration the unit of advancement which is the command of specific knowledge, besides focusing on the participant and her actual set of skills. In light of this, there are two terminologies that are brought to the forefront in

movimento-pela-conciliacao/qualidade-em-conciliao-orientaes-a-conciliadores.zip, accessed on December 20, 2011.

${ }^{23}$ See Definition page for the Tuning Project website: http://www.unideusto.org/ tuningeu/competences.html, accessed on April 3rd, 2015.

${ }^{24}$ Benedito Milioni, Dicionário de termos de recursos humanos (Dictionary of Human Resources Terminology) (São Paulo: Central de Negócios, 2003). 
training based on competences: i) skills (a set of tasks developed as part of a specific level of proficiency when necessary) and ii) aptitude (a skill developed in specific standards as a result of technical knowledge and proper stance or purpose).$^{25}$

In such a context, a competent mediator might be defined as (s)he who is able to develop a skill for applying a mediation theory with adequate stance and attitude. The doctrine describes ${ }^{26}$ the essential elements of a training system based on competences: 1) Competences must be attained after a close scrutiny of the training process; 2) Criteria, task assessment and conditions on which such skills will be lead must be made patent and public; 3) the teaching program must foster the individual development and the assessment of each of the necessary competences; 4) the assessment of the level of attainment of competences must consider the necessary attitudes and required performance levels. The Handbook of Court Mediation codifies mediation competences as those provided in specific mediation doctrines with minor adaptations. ${ }^{27}$

\section{Mediation Competences}

As already described above, the progressive development of mediation competences might be analyzed through the perspective of expectations regarding the behavior and performance of the mediator throughout each stage of his qualification process. One can expect specific conduct even from neophytes, for instance, perceiving conflict as a potentially positive phenomenon. The sequence of developments elaborated in the tables below was based on suggestions of the mediation doctrine ${ }^{28}$ and on the analysis of

25 John Foyster, Getting to Grips with Competency-Based Training and Assessment (Leabrook, Australia: TAFE National Centre for Research and Development, 1990).

${ }^{26}$ Nestor Norton, "Competency-Based Education and Training: A Humanistic and Realistic Approach to Technical and Vocational Instruction," in Achieving Professional Excellence - Proceedings of the National Conference on Performance Based Approach to Training, ed. Louis Harrington and David Kallamas (Columbus: National Center for Research in Vocational Training, 1985).

${ }^{27}$ Richard J. Bodineand Donna K.Crawford, The Handbook of Conflict Resolution Education: A Guide to Building Quality Programs in School (New York: Ed. Jossey-Bass, 1997).

${ }^{28}$ See Fred Schrumpf, Richard J. Bodine, and Donna K. Crawford, Peer mediation: conflict resolution in schools: program guide (Research Press, 1997); Mieke Brandon,"Competency based training for family and child mediators," ADR Bulletin 3, vol. 4, 2001; David A. Cruickshank, "Training mediators: moving towards competency based 
mediator qualification programs both in Brazil and abroad. There has been no intention to imply comprehensiveness as we listed the skills and conducts or sets of behaviors correlated to each of such skills. The following tables are to be used merely as a learning reference.

As already mentioned, a majority of the mediator qualification programs yielding positive results share a predominant trait: the planning of such qualification and development of mediation skills. The Brazilian experience ${ }^{29}$ has indicated that, generally speaking, a mediator qualification course must be conceived to transmit to the participants the basic skills indicated in the following tables. The mediator will progressively develop her skills through supervision and user assessment as she effectively seeks for continual improvement.

For instance, in a mediation course the negotiation skills taught are the bare minimum in order for the mediator to conduct her craft. Regarding negotiation skills, the aspiring mediator is expected to read supplementary material and to have discussions with his supervisors in order to attain specific improvements in the negotiation métier. For this reason, we observed that it takes a good number of years for a mediator to qualify. Generally speaking, skills were divided into basic, intermediary and advanced levels so that a mediator who has recently graduated from basic training may be able to gauge his development. It is also noteworthy that a new mediator may also have his/her development linked to personal (and familial) traits, bringing a rather subjective experience to each conflict and its ensuing resolution.

As a conclusion, the mediation qualification program involving practice of mediation should necessarily be devised in a way so as to meet specific needs of future participants and mediators. The following tables are to be used only as a guide because the most frequent means through which mediators will develop and become ever more proficient in the mediation praxis is through training and supervision.

training," in A Handbook of Dispute Resolution: ADR in Action, ed. Karl Mackie (Routledge, 1991).

29 See André G. Azevedo, "Autocomposição e processos construtivos: uma breve ana 'lise de projetos-piloto de mediação forense e alguns de seus resultados," (Mediation and Constructive Processes; a Brief Analysis of Forensic Mediation Pilot Projects and Some Results), ed. André Gomma de Azevedo, in Estudos em Arbitragem, Mediação e Negociação. Vol. 3, ed. André Gomma de Azevedo (Brasilia: Grupos de Pesquisa, 2003), 137-161. 


\section{Cognitive Competences Regarding Conflict}

Cognitive competences regarding conflict are those concerning the means through which awareness is acquired about conflict per se, how conflict is developed (its spiral) ${ }^{30}$ and its intrinsic traits. The essence of such conflicts consists in perceiving conflict as a natural phenomenon regarding any given relationship and analyzing it in the best possible way so as to best use its potential for growth. As a learning reference, one might state that such skills are developed in the following way:

\begin{tabular}{|c|c|c|}
\hline Basic Development & Intermediary Development & Advanced Development \\
\hline $\begin{array}{l}\text { One understands that } \\
\text { conflict is something } \\
\text { natural, inevitable and } \\
\text { that it has the potential } \\
\text { to be a positive force } \\
\text { towards growth. }\end{array}$ & $\begin{array}{l}\text { One recognizes that } \\
\text { the origins of conflict } \\
\text { and the resolving } \\
\text { processes of the conflict } \\
\text { resolution problems } \\
\text { are applicable to all } \\
\text { types of conflict, be } \\
\text { them of interpersonal, } \\
\text { intergroup, or } \\
\text { international nature. }\end{array}$ & $\begin{array}{l}\text { One maintains and } \\
\text { stimulates others to } \\
\text { have a variety of good } \\
\text { relationships with } \\
\text { colleagues, parties, } \\
\text { lawyers and judges. }\end{array}$ \\
\hline $\begin{array}{l}\text { One realizes that in } \\
\text { continual relationships, } \\
\text { conflict can be better } \\
\text { resolved through } \\
\text { cooperation. }\end{array}$ & $\begin{array}{l}\text { One understands that a } \\
\text { conflict might improve } \\
\text { or worsen depending } \\
\text { on the answer chosen } \\
\text { and conflict resolution } \\
\text { strategy used (and } \\
\text { fosters the same in } \\
\text { others). }\end{array}$ & $\begin{array}{l}\text { One analyzes the } \\
\text { conflict presented by } \\
\text { the parties in a context } \\
\text { of a present relationship } \\
\text { and utilizes an adequate } \\
\text { problem resolution } \\
\text { strategy. }\end{array}$ \\
\hline $\begin{array}{l}\text { One is aware that the } \\
\text { responses to specific } \\
\text { types of conflicts might } \\
\text { be improved in order } \\
\text { to reach one's actual } \\
\text { interests. }\end{array}$ & $\begin{array}{l}\text { One demonstrates } \\
\text { effective responses } \\
\text { to another in shared } \\
\text { conflicts and efficiently } \\
\text { chooses results with } \\
\text { starker or smoother } \\
\text { responses. }\end{array}$ & $\begin{array}{l}\text { One recognizes patterns } \\
\text { in responses to conflict } \\
\text { and plans systemic } \\
\text { improvements in order } \\
\text { to allow the user a } \\
\text { positive growth and } \\
\text { consequently, changes } \\
\text { to such patterns. }\end{array}$ \\
\hline
\end{tabular}

${ }^{30}$ Morton $v$. Deustch, The Resolution of Conflict: Constructive and Destructive Processes (New Haven: Yale University Press, 1977); Remo F. Entelman, Teoria de Conflictos: Hacia un nuevo paradigma (Barcelona: Gedisa, 2002); North, Brody and Holsti, Some empirical data on the conflict spiral, Peace Research Society Papers I, 1964 (Osgood, 1962, 1966); Richardson, 1967. 
One participates in attempts directed towards stimulus for cooperation and understands that conflict resolution skills are proficiencies for life.
One is able to communicate to parties the notion that conflict resolution skills are aids for life.
One is able to identify peacemaking and agitating behaviors and tactfully stimulates others to elect peacemaking actions.

\section{Perceptive Competences}

Perceptive competences are those relating to how one learns or perceives the facts and the context to which one is being exposed. Such competences essentially consist of understanding that a single fact or context might be perceived in various forms. Based on this set of perspectives, one should choose an approach that will ease the accomplishment of actual interests of both parties or of the mediator herself.

For instance, in a community mediation setting the mediator listens to a mother addressing her son, "You are stupid. You could easily choose what you could become but you insist on befriending Ricardo who is a bad egg." In such a context, the mediator could interpret the statement in various forms. For instance, judgmentally (and setting his mediator role aside) he could sense the terrible and maternally incompetent mother cannot even converse and raise her child. As a father (again, setting his mediator role aside), he could sense the hardship the mother is faced with as she is unable to avoid her son's bad decisions. As a mediator (seeking to identify issues, interests and feelings), he could sense the statement as a manifestation of a mother who loves her child and seeks his wellbeing and wishes to use the mediation opportunity in the best possible manner in order to establish effective solutions for the issues facing both son and mother. One realizes that as he proceeds with the summary, the mediator will opt for this perspective (or another similar one) as a means of using mediation to lead the situation towards an effective resolution.

For instructional sake, one can affirm that such skills are developed as in the following table: 


\begin{tabular}{|c|c|c|}
\hline Basic Development & Intermediary Development & Advanced Development \\
\hline $\begin{array}{l}\text { One accepts that he is } \\
\text { not always right and } \\
\text { identifies / verifies } \\
\text { his own preconceived } \\
\text { ideas regarding a given } \\
\text { situation. }\end{array}$ & $\begin{array}{l}\text { One accepts the fact } \\
\text { that one is not always } \\
\text { right and identifies } \\
\text { / verifies his own } \\
\text { preconceived ideas } \\
\text { regarding a given } \\
\text { situation. }\end{array}$ & $\begin{array}{l}\text { One critically analyses } \\
\text { one's own perceptions } \\
\text { and is able to listen } \\
\text { to statements trying } \\
\text { to identify actual } \\
\text { interests without being } \\
\text { judgmental towards any } \\
\text { of the parties. }\end{array}$ \\
\hline $\begin{array}{l}\text { One accepts the fact } \\
\text { that others might } \\
\text { perceive facts and } \\
\text { actions in a different } \\
\text { way and understands } \\
\text { how others might } \\
\text { perceive contexts, facts } \\
\text { and actions. }\end{array}$ & $\begin{array}{l}\text { One precisely and } \\
\text { empathically identifies } \\
\text { how contexts, facts and } \\
\text { actions are perceived by } \\
\text { others. }\end{array}$ & $\begin{array}{l}\text { One is able to foster } \\
\text { perceptive changes } \\
\text { in parties regarding } \\
\text { contexts, facts and } \\
\text { actions and is able to } \\
\text { avoid the escalating of } \\
\text { conflict between parties. }\end{array}$ \\
\hline $\begin{array}{l}\text { One analyses a conflict } \\
\text { from the perspective } \\
\text { of actual and unmet } \\
\text { interests and avoids } \\
\text { discussions based on } \\
\text { guilt but rather directs } \\
\text { the dialogue towards } \\
\text { solutions. }\end{array}$ & $\begin{array}{l}\text { One identifies obstacles } \\
\text { for perception of } \\
\text { the parties and } \\
\text { lawyers regarding the } \\
\text { conflicting context. }\end{array}$ & $\begin{array}{l}\text { One develops strategies } \\
\text { to stimulate changes in } \\
\text { the parties' and lawyers' } \\
\text { perception linking these } \\
\text { perceptions to more } \\
\text { favorable contexts } \\
\text { towards dispute } \\
\text { resolution. }\end{array}$ \\
\hline $\begin{array}{l}\text { One differentiates } \\
\text { between peacemaking } \\
\text { and agitating behaviors } \\
\text { throughout one's own } \\
\text { actions and also that of } \\
\text { others throughout the } \\
\text { mediation. }\end{array}$ & $\begin{array}{l}\text { One is able to } \\
\text { stimulate change in } \\
\text { agitating actions into } \\
\text { peacemaking actions } \\
\text { and conducts the } \\
\text { mediation with poise. }\end{array}$ & $\begin{array}{l}\text { One is able to stimulate } \\
\text { the parties to perceive } \\
\text { peace as a desired } \\
\text { condition and to } \\
\text { understand it as a result } \\
\text { of concrete actions (and } \\
\text { not only intentions). }\end{array}$ \\
\hline $\begin{array}{l}\text { One is able to stimulate } \\
\text { parties to perceive peace } \\
\text { as a desired condition } \\
\text { and to understand it } \\
\text { as a result of concrete } \\
\text { actions (and not only } \\
\text { intentions). }\end{array}$ & $\begin{array}{l}\text { One effectively } \\
\text { confronts any bias } \\
\text { (one's own and that of } \\
\text { others) in the working } \\
\text { environment. }\end{array}$ & $\begin{array}{l}\text { One is able to } \\
\text { distinguish between } \\
\text { bias and contempt and } \\
\text { understands disparate } \\
\text { answers regarding the } \\
\text { positional conflict of } \\
\text { negotiation based on } \\
\text { interests. }\end{array}$ \\
\hline
\end{tabular}




\section{Emotional Competences}

Emotional competences relate to the ability to processes the set of emotional stimuli to which one is exposed. Such competences essentially consist of establishing the fact that all individuals have feelings and that each person must be accountable for one's own emotions. Other people only furnish the stimulus.

Suppose a mother bearing some emotional aptitude listens to her four year old son vociferates, "I hate you" for not having been allowed to watch a movie at 9:30 p.m. She should not become emotionally unbalanced. As the mother is responsible for her own feelings and must understand the "I hate you" as "I feel sleepy". Likewise, a mediator with some well-chiseled emotional skills should not feel distressed if she hears from a lawyer, "You are not mediating properly". The mediator should not understand that stimulus as an insult, but rather as a request for clarification regarding a specific approach or even regarding the mediation procedure. As a learning assistance tool, one could state that such skills can be learned according to the following table:

\begin{tabular}{|c|c|c|}
\hline Basic Development & Intermediary Development & Advanced Development \\
\hline $\begin{array}{l}\text { One knows that the } \\
\text { feelings of rage, } \\
\text { frustration and fear are } \\
\text { natural and is able to } \\
\text { understand one's own } \\
\text { emotions. }\end{array}$ & $\begin{array}{l}\text { One takes responsibility } \\
\text { for one's emotions and } \\
\text { does not blame others } \\
\text { for being the cause } \\
\text { (but rather, just the } \\
\text { stimulus). }\end{array}$ & $\begin{array}{l}\text { One remains calm and } \\
\text { focused on solving } \\
\text { issues even when faced } \\
\text { with stark emotional } \\
\text { manifestations for } \\
\text { others (either parties or } \\
\text { lawyers). }\end{array}$ \\
\hline $\begin{array}{l}\text { One controls rage in } \\
\text { most of the conflicts one } \\
\text { is involved in. }\end{array}$ & $\begin{array}{l}\text { One understands that } \\
\text { others have different } \\
\text { emotional responses } \\
\text { from yours. }\end{array}$ & $\begin{array}{l}\text { One accepts and } \\
\text { validates emotions } \\
\text { and perceptions from } \\
\text { others and stimulates } \\
\text { emotional responses } \\
\text { which are more } \\
\text { compatible with actual } \\
\text { interests on the side } \\
\text { of the parties and } \\
\text { stakeholders. }\end{array}$ \\
\hline $\begin{array}{l}\text { One adequately } \\
\text { expresses emotions. }\end{array}$ & $\begin{array}{l}\text { One knows the effective } \\
\text { strategies to control the } \\
\text { more heated tempers } \\
\text { and uses them in a } \\
\text { timely manner. }\end{array}$ & \\
\hline
\end{tabular}




\begin{tabular}{|l|l|l|}
\hline $\begin{array}{l}\text { One listens to and } \\
\text { identifies others' } \\
\text { feelings. }\end{array}$ & $\begin{array}{l}\text { One is able to disagree } \\
\text { without being } \\
\text { disagreeable. }\end{array}$ & $\begin{array}{l}\text { One diverges and } \\
\text { transforms the debate } \\
\text { into a positive or } \\
\text { pleasant experience. }\end{array}$ \\
\hline $\begin{array}{l}\text { One does not react } \\
\text { by raising one's own } \\
\text { response as a reaction } \\
\text { to others' emotional } \\
\text { bursts. }\end{array}$ & $\begin{array}{l}\text { One is able to recognize } \\
\text { and validate feelings. }\end{array}$ & $\begin{array}{l}\text { One uses stimulus } \\
\text { approaches towards } \\
\text { the development of } \\
\text { emotional abilities. }\end{array}$ \\
\hline
\end{tabular}

\section{Communicative Competences}

Communicative competences are those relating to the means through which one communicates the set of intended messages. Such competences consist of establishing that each shall be accountable for the way messages are understood (i.e., one should know "how to request") and the way the interlocutors's messages are understood (i.e., one should know "how to listen", what the other is requesting).

The means of communication in mediation directly influences the end result of the mediation process. Conciliatory communication is one of the approaches used with repeated success. Conciliatory (or depolarizing) communication consists of the communicative process where information is communicated and received so as to stimulate reciprocal understanding and the attaining of the interlocutors' actual interests. The core premise of conciliatory communication involves listening to implicit requests contained in the speech in order to drive communication towards the attainment of such interests or needs. For instance, as a party states, "If he does not hand me back my drill I will report him to the police department for misappropriation". Here a mediator might interpret this speech as a rudimentary request. The party might be actually saying, "I would like to be respected and once again enjoy a good relation with my neighbor and to be validated by being addressed with considerateness. Thus, I'd like to have my drill back with the due mention of gratitude for the loan." A fundamental aspect of conciliatory communication involves listening to affronts or threats as "inept communicative requests".

Conciliatory communication argues for more rudimentary registers of communication so as to seek more satisfactory results for both negotiating parties. One might suggest that mediation also consists of catalyzed communication of a third party (the mediator) who is skillful in communicating and able to transform conflict into an opportunity to understand and meet the 
needs (one's own and that of others). Thus, language is the main tool for mediators, for by using effective communication one is able to understand explicit and implicit interests and to handle the perceptive transformation, from conflict of a negative phenomenon into a positive factor for those being mediated.

Not every negotiation and communication is able to attain potential gains imbedded in conflicts. The mediator's participation will make a difference in such scenarios. For instructional purposes, there is a communication classification that brings people closer together and stimulates mutual understanding in conciliatory, empathic or transforming communication. Contrary to what takes place in a conciliatory communication (which demands training of one's communication skills), we are used to a polarizing communication (also dubbed as violent communication) which is a means of keeping people apart and weakening the social bond between them. A better understanding of both forms of communication, are presented on the table below:

\begin{tabular}{|c|c|}
\hline Conciliatory Communication & Polarizing Communication \\
\hline $\begin{array}{l}\text { There is a focus on solutions while } \\
\text { observing facts. A conciliatory speech } \\
\text { stimulates cooperative or depolarized } \\
\text { relationships. For instance, when } \\
\text { an experienced mediator realizes } \\
\text { the attorney is having a hard time } \\
\text { understanding the best way to act } \\
\text { in a specific stage of the process, } \\
\text { and says, "Dr. Oswald, Thank you } \\
\text { for participating. I see that you are } \\
\text { a diligent attorney and is intent in } \\
\text { resolving the issues as promptly as } \\
\text { possible. I am curious to hear you and } \\
\text { discuss your proposals accordingly, } \\
\text { and I believe that we will be able to } \\
\text { do that in } 5 \text { to } 10 \text { minutes. Prior to } \\
\text { that I would like to listen to those } \\
\text { involved in order to certify that every } \\
\text { aspect regarding this mediation has } \\
\text { been communicated, and after that } \\
\text { we will come back to your point, } \\
\text { is that ok?" By acting this way the } \\
\text { mediator is fostering cooperative } \\
\text { behaviors, and through this, she will } \\
\text { tactfully and practically be assisting } \\
\text { the attorney. }\end{array}$ & $\begin{array}{l}\text { There is a focus on blame by } \\
\text { explicitly or implicitly judging others' } \\
\text { behaviors. An adjudicative speech } \\
\text { usually stimulates antagonistic or } \\
\text { polarized relationships. For instance, } \\
\text { when an inexperienced mediator is } \\
\text { vexed when realizing the attorney is } \\
\text { rather uncooperative and says, "Dr. } \\
\text { Oswald, you are one of the most } \\
\text { challenging attorneys I have worked } \\
\text { with." By doing this, the mediator will } \\
\text { hardly see any collaborative behaviors } \\
\text { from this attorney. Judging and } \\
\text { comparing (also a form of judgment) } \\
\text { polarize and cause resistance, and } \\
\text { very rarely will lead to the desired } \\
\text { transformation. }\end{array}$ \\
\hline
\end{tabular}




\begin{tabular}{|c|c|}
\hline Conciliatory Communication & Polarizing Communication \\
\hline $\begin{array}{l}\text { Requests are presented as } \\
\text { efficacious expressions through } \\
\text { which feelings and needs are } \\
\text { communicated. Requests in } \\
\text { conciliatory communication involve in } \\
\text { the manifestation of an individual's } \\
\text { interests or needs and convey the } \\
\text { expectation this party has of resolving } \\
\text { not only their own needs, but also } \\
\text { signals an intention to have the } \\
\text { interlocutor needs met also. Requests, } \\
\text { when properly communicated, convey } \\
\text { a sense of a win-win scenario. For } \\
\text { instance, an interested party could } \\
\text { say, "I'd like you to hand me back } \\
\text { my drill. I would deeply appreciate a } \\
\text { good relationship with you and I have } \\
\text { sensed that you would appreciate the } \\
\text { same. I am in need of the drill I have } \\
\text { lent you a couple months ago, and I } \\
\text { believe that the best way to maintain } \\
\text { our good standing is to simply ask } \\
\text { for the tool in a straightforward way. } \\
\text { By acting this way I will convey my } \\
\text { intention, which is to continue being } \\
\text { your good neighbor and enjoying } \\
\text { your friendship." }\end{array}$ & $\begin{array}{l}\text { Requests are presented as demands } \\
\text { or even insults. Such demand involves } \\
\text { that which is claimed back as a } \\
\text { fundamental link to meet needs and } \\
\text { aspirations without clearly indicating } \\
\text { a willingness to negotiate. Demands } \\
\text { usually signal that the denial to meet } \\
\text { one's expectation will lead to loss } \\
\text { to the denying party. An inefficient } \\
\text { means of presenting a request is } \\
\text { through insulting. Quite often a } \\
\text { few of the mediation program users } \\
\text { resort to mediation exactly because } \\
\text { they were not apt in conveying their } \\
\text { requests. For instance, when a party } \\
\text { addresses his neighbor, "Robert, If } \\
\text { I ever knew you were such a crook } \\
\text { I'd never lend you my drill." Deep } \\
\text { down he might be trying to say, "I am } \\
\text { quite disappointed in you and feel } \\
\text { disrespected by your delay in handing } \\
\text { me back my drill. I'd like to have my } \\
\text { drill back and to hear an explanation } \\
\text { for such wait so that we might again } \\
\text { enjoy being good neighbors. }\end{array}$ \\
\hline $\begin{array}{l}\text { Speeches have a predominantly } \\
\text { prospective approach. The } \\
\text { collaborative stance in conciliatory } \\
\text { communication is characterized } \\
\text { by having individuals accountable } \\
\text { regarding intended goals and the } \\
\text { means through which these goals } \\
\text { will be conveyed to others. One seeks } \\
\text { to take on responsibility for the end } \\
\text { result of the negotiation by adapting } \\
\text { the speech to meet stakeholders' } \\
\text { actual interests. }\end{array}$ & $\begin{array}{l}\text { Speeches convey a predominantly } \\
\text { retrospective approach. A judgmental } \\
\text { stance in a polarized communication } \\
\text { involves in transferring the } \\
\text { accountability of intended goals unto } \\
\text { others. This way of communicating } \\
\text { will often attribute to another the } \\
\text { responsibility for not having attained } \\
\text { one's own interest. }\end{array}$ \\
\hline $\begin{array}{l}\text { Speeches are directed to the attaining } \\
\text { of actual interests and to the } \\
\text { validating of feelings - the premise } \\
\text { for understanding and empathy. }\end{array}$ & $\begin{array}{l}\text { Speeches are directed towards } \\
\text { the apparent interests and usually } \\
\text { disregard or invalidate feelings. }\end{array}$ \\
\hline
\end{tabular}


As an instructional reference and as means of following one's learning experience, one can affirm that communicative skills are developed as follows:

\begin{tabular}{|l|l|l|}
\hline \multicolumn{1}{|c|}{ Basic Development } & Intermediary Development & \multicolumn{1}{|c|}{ Advanced Development } \\
\hline $\begin{array}{l}\text { One listens without } \\
\text { interrupting while the } \\
\text { interlocutor describes an } \\
\text { incident or defines the } \\
\text { problem. }\end{array}$ & $\begin{array}{l}\text { One summarizes facts } \\
\text { and feelings from } \\
\text { the point of view of } \\
\text { the other in order to } \\
\text { alleviate anger and } \\
\text { deescalate conflict. }\end{array}$ & $\begin{array}{l}\text { One summarizes } \\
\text { positions and others' } \\
\text { interests with efficacy, } \\
\text { precision and empathy } \\
\text { in conflict situations. }\end{array}$ \\
\hline $\begin{array}{l}\text { One avoids presenting } \\
\text { ones' opinion } \\
\text { prematurely and is fully } \\
\text { open to persuasion. }\end{array}$ & $\begin{array}{l}\text { One elaborates } \\
\text { specific questions that } \\
\text { might gather more } \\
\text { information. }\end{array}$ & $\begin{array}{l}\text { One recognizes } \\
\text { and validates other } \\
\text { people's emotions and } \\
\text { perspectives. }\end{array}$ \\
\hline $\begin{array}{l}\text { One formulates } \\
\text { questions such as, "How } \\
\text { did you feel about it?", } \\
\text { and, "What happened } \\
\text { next?" }\end{array}$ & $\begin{array}{l}\text { One elects proper } \\
\text { phraseology to problem } \\
\text { solving, "e.g., 'and' } \\
\text { rather than 'but', 'we', } \\
\text { rather than 'I' and } \\
\text { 'you'.) }\end{array}$ & $\begin{array}{l}\text { One reformulates } \\
\text { others' statements } \\
\text { extracting inflamed } \\
\text { and biased messages in } \\
\text { order to capture latent } \\
\text { meanings. }\end{array}$ \\
\hline $\begin{array}{l}\text { One responds to } \\
\text { questions regarding } \\
\text { the conflict and does } \\
\text { not dodge an open talk } \\
\text { about divergences. }\end{array}$ & $\begin{array}{l}\text { One addresses others on } \\
\text { the first person singular } \\
\text { instead of the second or } \\
\text { third person in order to } \\
\text { express a point of view. }\end{array}$ & $\begin{array}{l}\text { One examines full } \\
\text { understanding, listens } \\
\text { to comprehend, and } \\
\text { expresses oneself in } \\
\text { order to be understood. }\end{array}$ \\
\hline $\begin{array}{l}\text { One opts for a conflict } \\
\text { resolution terminology } \\
\text { (e.g., actual interest, } \\
\text { integrative negotiation, } \\
\text { MAANA, point of view, } \\
\text { etc.) }\end{array}$ & $\begin{array}{l}\text { One demonstrates } \\
\text { awareness in non-verbal } \\
\text { communication, both } \\
\text { one's own and that } \\
\text { of others, especially } \\
\text { regarding feelings. }\end{array}$ & $\begin{array}{l}\text { One rebuilds one's } \\
\text { affirmation using less } \\
\text { inflamed and unbiased } \\
\text { language and opts for } \\
\text { questions designed to } \\
\text { clarify actual and tacit } \\
\text { interests. }\end{array}$ \\
\hline
\end{tabular}

\section{Competences for Creative Thinking}

Competences for creative thinking are defined by the means through which one develops solutions for concrete and hypothetical problems. Such competences of creative thought essentially involve stimulating the pursuit of solutions through innovative, unprecedented or alternative paths. 
As a learning reference, one might affirm that the creative thought skills are developed as presented on the follows table:

\begin{tabular}{|c|c|c|}
\hline Basic Development & Intermediary Development & Advanced Development \\
\hline $\begin{array}{l}\text { One describes what is } \\
\text { aspired and why. }\end{array}$ & $\begin{array}{l}\text { One distinguishes } \\
\text { between positions and } \\
\text { interests (or between } \\
\text { apparent and actual } \\
\text { interests). }\end{array}$ & $\begin{array}{l}\text { One understands that } \\
\text { actual interests (and not } \\
\text { positions or apparent } \\
\text { interests) define the } \\
\text { problem in conflict } \\
\text { situations. }\end{array}$ \\
\hline $\begin{array}{l}\text { One generates ideas to } \\
\text { solve the problems at } \\
\text { hand. }\end{array}$ & $\begin{array}{l}\text { One identifies interests } \\
\text { that go beyond one's } \\
\text { own position in any } \\
\text { given situation. }\end{array}$ & $\begin{array}{l}\text { One prioritizes interests } \\
\text { and develops strategies } \\
\text { intending agreement, } \\
\text { e.g., focusing first on } \\
\text { the easiest subjects. }\end{array}$ \\
\hline $\begin{array}{l}\text { One improves a simple } \\
\text { idea. }\end{array}$ & $\begin{array}{l}\text { One understands } \\
\text { and starts to employ } \\
\text { analytical tools to } \\
\text { diagnose problems. }\end{array}$ & \\
\hline $\begin{array}{l}\text { One identifies mutual } \\
\text { and compatible interests } \\
\text { and creates behavioral } \\
\text { options to satisfy such } \\
\text { interests. }\end{array}$ & $\begin{array}{l}\text { One changes } \\
\text { perspectives in order to } \\
\text { allow for new options. }\end{array}$ & $\begin{array}{l}\text { One aptly manages } \\
\text { the flow of ideas } \\
\text { (brainstorming) } \\
\text { dissociating solution } \\
\text { development from } \\
\text { choice or decision in } \\
\text { regards to the best } \\
\text { possible option. }\end{array}$ \\
\hline
\end{tabular}

\section{Competence of Negotiation}

Competences of negotiation are defined as those involving the use of persuasion or negotiation tools. Such skills involve an understanding of negotiation theory and the ability to apply it to daily activities.

As a learning reference, one might affirm that the negotiation skills are developed as follows: 


\begin{tabular}{|l|l|l|}
\hline \multicolumn{1}{|c|}{ Basic Development } & Intermediary Development & \multicolumn{1}{|c|}{ Advanced Development } \\
\hline $\begin{array}{l}\text { One is able to } \\
\text { participate in } \\
\text { negotiating with } \\
\text { low levels of anxiety } \\
\text { and with the use of } \\
\text { techniques. }\end{array}$ & $\begin{array}{l}\text { One easily performs } \\
\text { negotiation with } \\
\text { principles (also dubbed } \\
\text { as negotiation based on } \\
\text { interests) }\end{array}$ & $\begin{array}{l}\text { One successfully } \\
\text { negotiates with parties } \\
\text { without significant } \\
\text { negotiating or } \\
\text { communication skills. }\end{array}$ \\
\hline $\begin{array}{l}\text { One understands that } \\
\text { almost all interactions } \\
\text { are negotiations. }\end{array}$ & $\begin{array}{l}\text { One stimulates parties } \\
\text { and attorneys to } \\
\text { negotiate in a more } \\
\text { technical expression. }\end{array}$ & $\begin{array}{l}\text { One teaches the } \\
\text { negotiation process } \\
\text { to the parties and } \\
\text { attorneys. }\end{array}$ \\
\hline
\end{tabular}

\section{Competence of Critical Thinking}

Competence of critical thinking are defined as the means through which one chooses one or more solutions for concrete or hypothetical problems. Such skills involve stimulating a conscious choice in face of a number of possible solutions.

As a learning reference, one might say that the critical thinking skills are developed according to the following table:

\begin{tabular}{|l|l|l|}
\hline \multicolumn{1}{|c|}{ Basic Development } & Intermediary Development & \multicolumn{1}{c|}{ Advanced Development } \\
\hline $\begin{array}{l}\text { One assesses risks } \\
\text { and consequences } \\
\text { of adversarial } \\
\text { confrontation in a } \\
\text { conflict. }\end{array}$ & $\begin{array}{l}\text { One makes use of } \\
\text { solution processes to } \\
\text { lead hearings in which } \\
\text { the parties are in } \\
\text { adversarial conflict. }\end{array}$ & $\begin{array}{l}\text { One presents procedural } \\
\text { options for the parties } \\
\text { to avoid adversarial } \\
\text { and counterproductive } \\
\text { confrontation }\end{array}$ \\
\hline $\begin{array}{l}\text { One identifies a } \\
\text { better alternative in } \\
\text { an adversarial conflict } \\
\text { situation. }\end{array}$ & $\begin{array}{l}\text { One stimulates parties } \\
\text { to rethink a better } \\
\text { alternative to the } \\
\text { negotiated agreements. }\end{array}$ & $\begin{array}{l}\text { One stimulates parties } \\
\text { to propose options in } \\
\text { long and short term } \\
\text { consequences }\end{array}$ \\
\hline $\begin{array}{l}\text { One stimulates parties } \\
\text { to seek for mutual } \\
\text { justice when possible } \\
\text { throughout a dispute } \\
\text { resolution instead of } \\
\text { attempting to conquer } \\
\text { an imposed victory. }\end{array}$ & $\begin{array}{l}\text { One analyses means to } \\
\text { improve even more the } \\
\text { best alternatives to the } \\
\text { negotiated agreement. }\end{array}$ \\
\hline
\end{tabular}




\begin{tabular}{|l|l|l|}
\hline $\begin{array}{l}\text { One expresses a realistic } \\
\text { and accomplishable plan } \\
\text { in order to resolve a } \\
\text { conflict. }\end{array}$ & $\begin{array}{l}\text { One identifies patterns } \\
\text { and justice criteria such } \\
\text { as rules or patterns as } \\
\text { one considers interests } \\
\text { and solutions. }\end{array}$ & $\begin{array}{l}\text { One analyzes willingness } \\
\text { and skills on both } \\
\text { parties in order to honor } \\
\text { an action plan in any } \\
\text { given situation. }\end{array}$ \\
\hline $\begin{array}{l}\text { One realizes that parties } \\
\text { might have a distinct } \\
\text { sense of justice then } \\
\text { one's own. }\end{array}$ & $\begin{array}{l}\text { One recognizes the } \\
\text { efficacy of commitment } \\
\text { only in fair, realistic and } \\
\text { manageable solutions. }\end{array}$ & $\begin{array}{l}\text { One identifies } \\
\text { uncontrollable factors } \\
\text { that might have an } \\
\text { impact on the parties' } \\
\text { skills to honor a } \\
\text { contract. }\end{array}$ \\
\hline
\end{tabular}

Other competences such as elaborating a term of agreement or organizing the surroundings and making it suitable for mediation are needed for the adequate development of the mediation praxis. The skills above have been listed in detail because these are the most relevant competences for the craft of the mediator. As mentioned previously, there is no intention to present this as a comprehensive list of all competences involved in mediation.

\section{Conclusions}

The assessment of individuals undertaking the rather delicate task of bringing people together (the purpose of mediation per se) isquite complex. The expectation that new mediators might be able to demonstrate competences presumes that they have honed the necessary skills to deal with more complex dilemmas. The Brazilian experience, however, has shown that through stimulating continuous improvement (such as through continued supervision, different forms of user assessment and self-supervising group formation) the goal of mediation qualification in advanced techniques proves to be attainable in the mid-run.

One also realizes that the current model based on competences has yet to fully develop. Currently, the refinement of mediation must take into account such elements as a service directed to meet the users's needs. In this sense, one of the most important traits that well-assessed legal mediators in Brazil have expressed is an actual concern for the involved parties. Such a zealous caring also calls for assessment, constant supervision, observation and training.

Besides fostering continual improvement, mediators' competence assessments contribute to the eradication of one of the most counterproductive beliefs in the métier: It is enough to be of goodwill in order to perform adequately. The Brazilian experience has also been positive in the sense that 
mediator assessment facilitates the understanding of those who have received rudimentary training about the need to deepen their preparation. The danger of allowing incompetent mediators who ignore these techniques is alarming to the point of recommending periodical assessments. The daunting implementation of such a model has already brought an awareness about the need for qualification. Consequently, the improvised forms of mediation and conciliation are slowly being phased out.

The Brazilian experience has also indicated that learning in mediation takes place not throughout the theoretical portion of training, nor with observation or with co-mediation, but rather with discussions with supervisors post co-mediating sessions or with self-supervising groups in which the techniques applied for each concrete case are discussed and each competency mentioned above can slowly be perfected. The slow changes to the public system of dispute resolution are proving that mediation is already an integral part of the Judiciary Branch and has assisted the fundamental role of the State to find its core identity, namely, that of bringing people together.

\section{Bibliography}

Arrow, Kenneth et al. Barriers to Conflict Resolution. New York: W. W. Norton \& Company, 1995.

Almeida, Fabio Portela Lopes de. "A teoria dos jogos: A teoria dos jogos: uma fundamentação teórica dos métodos de resolução de disputa.” In André Gomma de Azevedo. (Org.). Estudos em Arbitragem, Mediação e Negociação (v. 02), edited by André Gomma de Azevedo, 175-199. Brasília: Editora Grupos de Pesquisa e Maggiore Editora, 2003.

Auerbach, Jerold S. Justice without Law? New York: Oxford University Press, 1983. Azevedo, André Gomma de. Estudos em Arbitragem, Mediação e Negociação, Brasília: Brasília Jurídica, 2002.

— . "O processo de negociação: Uma breve apresentação de inovações epistemológicas em um meio autocompositivo." Revista dos Juizados Especiais do Tribunal de Justiça do Distrito Federal e Território 11 (2001): 13-24.

- Estudos em arbitragem, mediação e negociação (vol. 2). Brasília: Grupos de Pesquisa, 2003.

- Estudos em arbitragem, mediação e negociação (vol. 3). Brasília: Grupos de Pesquisa, 2003.

- Estudos em arbitragem, mediação e negociação (vol. 4). Brasília: Grupos de Pesquisa, 2003..

Azevedo, Gustavo T. "Confidencialidade na mediação." In Estudos em arbitragem, mediação e negociação (vol. 2), edited by André Gomma de Azevedo, 303-324. Brasília: Grupos de Pesquisa, 2003. 
Babu, Annie et al. Guide de la médiation familiale: Étape par étape. Paris: Érès, 2006.

Barbado, Michelle T. "Um novo perfil para a advocacia: o exercício profissional do advogado no processo de mediação." In Estudos em arbitragem, mediação e negociação (vol. 2), edited by André Gomma de Azevedo, 369-381. Brasília: Grupos de Pesquisa, 2003.

Baruch Bush, Robert et al. The Promise of Mediation: Responding to Conflict Through Empowerment and Recognition. São Francisco: Jossey-Bass, 1994.

Baruch Bush, Robert A. "One Size Does Not Fit All: A Pluralistic Approach to Mediator Performance Testing and Quality Assurance." Ohio State Journal on Dispute Resolution 19 (3): 965-1004.

Birke, Richard, and Craig R Fox. "Psychological Principles in Negotiating Civil Settlements." Harvard Negotiation Law Review 4 (1999): 1-57.

Bradenburger, Adam, and Barry Nalebuff. Co-opetition. New york: Currency Doubleday, 1996.

Brams, Steven, and Alan Taylor. Fair Division: From Cake-cutting to Dis- pute Resolution. London: Cambridge University Press, 1996.

Brazil, Wayne D. "For Judges: Suggestions About What to Say About ADR at Case Management Conferences - and How to Respond to Concerns or Objections Raised by Counsel." In Ohio State Journal on Dis- pute Resolution 16 (2000): 165-179.

Bunker, Barbara B. et al. Conflict, Cooperation \& Justice: Essays Inspired by the Work of Morton Deutsch. San Francisco: Jossey-Bass, 1995.

Calcaterra, Rubén A. Mediación Estrategica, Barcelona: Gedisa, 2002.

Capeletti, Mauro, and Bryant Garth. Acesso à Justiça. Porto Alegre: Sérgio Antônto Fabris, 1988.

Carnelutti, Francesco. Sistema de Direito Processual Civil vol. 1. São Paulo: Bookseller, 2001.

Carver, Todd B., and Albert A Vondra. "Alternative Dispute Resolution: Why it doesn't work and why it does." Harvard Business Review, 1994.

Cooley, John. The Mediator's Handbook. Notre Dame (IL): Nita, 2000.

Deutsch, Morton. The Resolution of Conflict: Constructive and Destructive Processes. New Haven: Yale University Press, 1973.

Deutsch, Morton et al. The Handbook of Conflict Resolution: Theory and Practice. San Francisco: Jossey Bass, 2000.

Elliott, E. Donald. "Managerial Judging and the Evolution of Procedure." University of Chicago Law Review 53 (1986): 306-336.

Entelman, Remo F. Teoria de Conflictos: Hacia un Nuevo paradigma. Barcelona: Gedisa, 2002.

Felix, Loussia Penha M, Carlos Eduardo Barbé Delacroix, Graciela Barranco Goyena, Rodrigo Coloma Correa, Guillermo Manuel Delmas Aguiar, Eduardo Víctor Lapenta, Eduardo Juan Morales Ordóñez, Ademar Pereira, Julio Alfredo Rivas Hernández, Eva Romano Urbina, and José Salvador Ventura del Toro. Higher Education in Latin America: reflections and perspectives on Law. Bilbao: Deusto Univerty Press, 2014 
Fiss, Owen. “Against Settlement.” Yale Law Journal 93 (1984): 1073-1090.

Fisher, Roger and William Ury. Como chegar ao Sim: A negociação de acordos sem concessões. São Paulo: Imago, 2005.

Folberg, Jay et al. Divorce and Family Mediation: Models, Techniques and Applications. New York: Guilford Press, 2004.

Golann, Dwight. Mediating Legal Disputes. New York: Little, Brown and Company, 1996.

Goldberg, Stephen B., Frank E.A. Sander, Nancy H. Rogers, and Sarah Rudolph Cole. Dispute Resolution: Negotiation, Mediation, and Other Processes. New York: Aspen Law \& Business, 1992, 2 ed.

Gómez, José Maria. "Justiça transicional, humanitarismo compassivo e ordem global liberal pós-guerra fria.” In Direitos Huanos: Justiça, Verdade e Memória, edited by Bethania Assy, Carolina Campos Melo, João Ricardo Dornelles and José María Gómez, 261-289. Rio de Janeiro: Lumen Juris, 2012.

Henning, Stephanie A. "A Framework for Developing Mediator Certification Programs." Harvard Negotiation Law Review 4 (1999): 189-203.

Hensler, Deborah R. "Does ADR Really Save Money? The Jury's Still Out." The National Law Journal (1994): 1-3.

_ . "Our Courts, Ourselves: How the Alternative Dispute Resolution Movement is Reshaping our Legal System." Penn State Law Review 108 (2003): 165-197.

Kakalik, James S, Terence Dunworth, Laural A. Hill, Daniel F. McCaffrey, Marian Oshiro, Nicholas M. Pace, and Mary E. Vaiana. An Evaluation of Mediation and Early Neutral Evaluation under the Civil Justice Reform Act. Santa Monica (CA): RAND Corp, 1996.

Kaufmann, Rodrigo de O. "Direitos Humanos, Direito Comparado e Universalismo: elementos para uma crítica pragmatista." In Direitos Humanos e Democracia: Algumas abordagens críticas, edited by George Rodrigo Bandeira Galindo, 103125. Curitiba: CRV, 2013.

Lambert, Danielle. Mediation familiale: Étape par étape . Québec: CCH LTÉE, 2002.

Mayer, Bernard. The Dynamics of Conflict Resolution: A Practitioner's Guide. San Francisco: Jossey-Bass, 2000.

- Beyond Neutrality: Confronting the Crisis in Conflict Resolution. San Francisco: Jossey-Bass, 2004.

Menkel-Meadow, Carrie. "Toward Another View of Negotiation: The Structure of Legal Problem Solving." UCLA L. 31 (1984): 403-411.

Menkel-Meadow, Carrie, Lela Porter Love, Andrea Kupfer Schneider, and Jean R Sternlight. Dispute Resolution: Beyond the Adversarial Model. Washington: Aspen Publishers, 2005.

Moffitt, Michael, and Robert C. Bordone. The Handbook of Dispute Resolution. San Francisco: Ed. Jossey Bass, 2005.

Mnookin, Robert, Scott R. Peppet, and Andrew S. Tulumello. Beyond Winning: Negotiating to Create Value in Deals and Disputes. Cambridge: Harvard University Press, 2000. 
Moore, Christopher. O processo de mediação. Porto Alegre: Artes Médicas, 1998.

Nolan-Haley, Jacqueline M. "Mediation And The Search For Justice Through Law." Washington University Law Quarterly 74 (1996): 47-74.

Plapinger, Elizabeth S. Court ADR: Elements of Program Design. New York: Center of Public Resources, 1992.

Riskin, Leonard. “Understanding Mediator's Orientations, Strategies, and Techniques: A Grid for the Perplexed." Harvard Negotiation Law Review 7, vol. 1 (1996): 7-49.

Risse, G. B., and Semmelweis, Ignaz Philipp. Dictionary of Scientific Biography (C.C. Gilespie, ed.). New York: Charles Scribner's Sons, 1980.

Rolph, Elizabeth S.; Moller, Erik. Evaluating Agency Alternative Resolution Programs: A User's Guide to Data Collection and Use, Santa Monica (CA): Rand Corp. 1995.

Rosenberg, Marshal. Comunicação não violenta: $t$ cnicas para aprimorar relacionamentos pessoais. Rio de Janeiro: Agora Editora, 2006.

Sander, Frank E. A. Varieties of Dispute Processing. In The Pound Conference, 70 Federal Rules Decisions, (1976), 111.

Rhode, Deborah L. In the Interests of Justice: Reforming the Legal Profession. New York: Oxford University Press, 2000.

Schmitz, Suzanne J. "What Should we Teach in ADR Courses - Concepts and Skills for Lawyers Representing Clients in Mediation." Harvard Negotiation Law Review 6 (2001): 189-201.

Ury, William. The Power of a Positive No: How to say no and still get to yes. New York: Bantam, 2007.

Villegas, Mauricio García. "Ineficacia del derecho y cultura del incumplimiento de reglas em América Latina." In El derecho em América Latina: Um mapa para el pensamento jurídico del siglo XXI, edited by César Rodríguez Garavito, 161184. Buenos Aires: Siglo Veintiuno Editores, 2011.

Yarn, Douglas E. Dictionary of Conflict Resolution. San Francisco (CA): JosseyBass Inc., 1999.

\section{Copyright}

Copyright for this article is retained by the Publisher. It is an Open Access material that is free for download, distribution, and or reuse in any medium only for non-commercial purposes; provided any applicable legislation is respected, the original work is properly cited, and any changes to the original are clearly indicated. 